\begin{tabular}{|c|}
\hline Studia Philosophiae Christianae \\
UKSW \\
$51(2015) 4$
\end{tabular}

ANDRZEJ KOBYLIŃSKI

Instytut Filozofii UKSW, Warszawa

\title{
SPRAWOZDANIE Z V OGÓLNOPOLSKIEGO KONWERSATORIUM Z CYKLU STYCZEŃ - ŚLIPKO - TISCHNER. INSPIRACJE CHRZEŚCIJAŃSKIE W ETYCE, AKADEMIA IGNATIANUM, KRAKÓW, 21 KWIETNIA 2015
}

21 kwietnia 2015 roku w Akademii Ignatianum w Krakowie odbyło się V Ogólnopolskie Konwersatorium z cyklu Styczeń - Ślipko - Tischner. Inspiracje chrześcijańskie w etyce. Konferencja została zorganizowana przez Katedrę Logiki i Teorii Poznania w Instytucie Filozofii Akademii Ignatianum w Krakowie oraz przez Sekcję Etyki w Instytucie Filozofii Uniwersytetu Kardynała Stefana Wyszyńskiego w Warszawie. Prezentowane spotkanie było kontynuacją czterech poprzednich konwersatoriów. Pierwsza konferencja $\mathrm{z}$ tego cyklu została zorganizowana 19 marca 2009 roku w UKSW w Warszawie. Tegoroczne obrady zostały poświęcone problemowi źródeł i motywacji w interpretacji doświadczenia moralnego. Głównym punktem odniesienia dla większości wystąpień w trakcie konferencji była najnowsza książka ks. Jakuba Gorczycy SJ pt. Zarys etyki fundamentalnej. Być dla drugiego ${ }^{1}$.

Otwarcia konwersatorium dokonał ks. prof. Ignatianum dr hab. Tomasz Homa SJ, dziekan Wydziału Filozoficznego Akademii Ignatianum w Krakowie, który w swoim wystąpieniu przybliżył kilkuletnią historię spotkań z cyklu Styczeń - Ślipko - Tischner. Inspiracje chrześcijańskie w etyce oraz zapowiedział problematykę tegorocznych obrad.

Sesji przedpołudniowej przewodniczył ks. dr Jacek Poznański SJ z Akademii Ignatianum w Krakowie. Pierwszy referat nt. Etos daru

Por. J. Gorczyca, Essere per l'altro. Fondamenti di etica filosofica, Gregorian \& Biblical Press, Roma 2011; wyd. pol.: Zarys etyki fundamentalnej. Być dla drugiego, Wydawnictwo WAM, Kraków 2014. 
wygłosił ks. prof. dr Jakub Gorczyca SJ z Papieskiego Uniwersytetu Gregoriańskiego w Rzymie. W swoim wystąpieniu prelegent ukazał wpływ koncepcji osoby ludzkiej jako daru na rozumienie wartości i norm moralnych. Człowiek jest podmiotem, który rozpoznaje siebie jako dar dla innych. Osoba ludzka stanowi byt samodzielny, odniesiony substancjalnie do drugiego człowieka. Zdaniem ks. Gorczycy, relacyjność należy do konstytutywnych elementów bytu ludzkiego. W konsekwencji można definiować osobę jako byt cielesno-duchowy, który istnieje jako dar dla innych.

Tego rodzaju koncepcja osoby ludzkiej wpływa na rozumienie wartości moralnych i cnót. Dobra moralnego doświadczamy w relacji z bliźnim. Jest ono ugruntowane w ontologicznej strukturze osoby, do której istoty należy darowanie się innym. Wartości moralne mają charakter relacyjny, wyrażają relacje międzyludzkie oraz charakteryzują osobowość człowieka. Natomiast cnoty jawią się w tej perspektywie jako różne przejawy doskonałości osoby. Istota cnoty to stały sposób bycia darem. Żeby być darem, trzeba najpierw kochać własne bycie oraz bycie innych ludzi.

Drugi referat zaprezentował ks. dr hab. Piotr Aszyk SJ z Papieskiego Wydziału Teologicznego w Warszawie nt. Etycy i Samarytanie. Samarytanin na bezludnej wyspie. Mówca podkreślił, że Samarytanin powinien stanowić wzorzec miłości bliźniego - niezależnie od wyznawanego światopoglądu czy religii. Tego rodzaju ujęcia miłości bliźniego nie akceptowali stoicy, dla których miłosierdzie było jedną z przywar. Byli oni przekonani, że człowiek mądry nie podlega wzruszeniu. Ks. Aszyk zauważył, że tak jak filozofia zaczyna się od zadziwienia, tak etyka zaczyna się od wzruszenia. Do postaci Dobrego Samarytanina nawiązywał często ks. Józef Tischner, dla którego ta postać biblijna stanowiła podstawę myślenia według wartości. Dobry Samarytanin nie występuje natomiast w pismach ks. Tadeusza Ślipki SJ, który w swojej refleksji etycznej świadomie rezygnował z jakichkolwiek odniesień do Pisma Świętego, aby w ten sposób precyzyjnie oddzielić porządek filozoficzny od teologicznego.

Trzeci referat w sesji przedpołudniowej został wygłoszony przez dr. Sebastiana Gałeckiego z Uniwersytetu Papieskiego Jana Pawła II 
w Krakowie nt. Etyka chrześcijańska wspótcześnie i jej „,differentiae specificae". Etyka chrześcijańska jest podzbiorem filozofii chrześcijańskiej - to wszystko, co odnosi się do filozofii chrześcijańskiej, odnosi się także do etyki chrześcijańskiej. Prelegent zwrócił uwagę na wielką różnorodność definicji filozofii chrześcijańskiej. W konsekwencji możemy wyróżnić tyle definicji etyki chrześcijańskiej, ile mamy różnych koncepcji filozofii chrześcijańskiej. Dr Gałecki podkreślił, że od XX wieku różne koncepcje etyki chrześcijańskiej wyrastają nie tylko z tomizmu czy neotomizmu, ale także $z$ wielu innych nurtów filozoficznych.

Czwarty referat w tej części obrad wygłosił ks. prof. KUL dr hab. Alfred Wierzbicki z Katolickiego Uniwersytetu Lubelskiego nt. Etyka a literatura. Perspektywa badawcza i dydaktyczna. Niezwykle ciekawym źródłem wiedzy o dylematach moralnych człowieka jest niewątpliwie literatura. Przykładem mogą być tragedie greckie (Antygona Sofoklesa, Obrona Sokratesa Platona) czy też niezwykłe książki Dostojewskiego. Zdaniem ks. Wierzbickiego, literatura pomaga przekazywać treści etyczne. Literatura wnosi bardzo dużo na polu badawczym i dydaktycznym etyki. Podobnie uważa amerykańska filozof Martha Nussbaum, która postuluje łączenie etyki z literaturą. Jej zdaniem, nie wystarczy poznanie czysto teoretyczne pewnych norm moralnych. W postawach bohaterów wierszy, opowiadań, powieści znajdujemy plastyczny obraz teorii moralnych oraz zyskujemy głębsze przekonanie na poziomie emocjonalnym. Dzięki pomocy literatury o wiele łatwiej utożsamić się z konkretną wizją życia moralnego.

Piątym referatem w sesji przedpołudniowej było wystąpienie ks. prof. dr. hab. Ryszarda Monia z Uniwersytetu Kardynała Stefana Wyszyńskiego w Warszawie nt. Źródta normatywności w etyce. W jakim stopniu myśl Emmanuela Lévinasa stanowi dopetnienie koncepcji personalistycznej Tadeusza Stycznia? Ks. Styczeń powtarzał często, że całą etykę da się streścić w 5 słowach: „Ja to wobec Ciebie powinienem". Powstaje tylko pytanie: Co dokładnie powinienem? I ono jest najtrudniejsze. By na nie odpowiedzieć, trzeba odwołać się ostatecznie do metafizyki, a zwłaszcza do antropologii. Styczeń rozpoczynał swoje rozważania etyczne od opisu doświadczenia moralności, a następnie odróżniał poczucie powinności od powinności, a także powinność 
od tego, co określał jako „powinne”, czyli treść powinności. Wolał on używać tego słowa, choć uważał, że jego synonimem może być słowo „miłość”, ale go unikał ze względu na jego konotację psychologiczną.

W jakim stopniu koncepcje Stycznia i Lévinasa mogą się uzupełniać? Zdaniem prof. Monia, można mieć co do tego spore wątpliwości. Lévinas wyraźnie odrzucał pojęcie osoby, gdyż ma ono konotacje bytowe. Poza tym był on przekonany, że drugi za każdym razem wyznacza stawkę mojej odpowiedzialności i że nie może być ona sprowadzona do wspólnego mianownika. Na dodatek każdy jest inny i niepowtarzalny. Nie da się zatem ustalić jednej normy postępowania właściwej dla każdego. Pomiędzy Styczniem a Lévinasem istnieje jednak pewne podobieństwo, gdyż obaj mówią o relacji międzyosobowej i obaj w jakiejś mierze zgadzają się co do tego, że ma ona charakter asymetryczny, gdyż także Styczeń mówi o tym, że każdy z nas istnieje ,,inaczej i wyżej”.

Szósty referat w porannej części obrad wygłosiła prof. UKSW dr hab. Ewa Podrez z Uniwersytetu Kardynała Stefana Wyszyńskiego w Warszawie nt. Etyka chrześcijańska czy chrześcijańska interpretacja etyki? Prelegentka zwróciła szczególną uwagę na to, że podstawowym problemem filozoficznym nowoczesnych teorii etycznych jest sama nowoczesność - w wymiarze teoretycznym i praktycznym. W czasach nowożytnych etyka oddziela się stopniowo od refleksji filozoficznej, stając się przede wszystkim przedmiotem publicznego dyskursu. Zasadnicza różnica między przednowoczesnymi a nowoczesnymi koncepcjami ładu moralnego polega na tym, że ten komponent jest obecnie cechą opisującą nas, ludzi, nie odnosi się już do Boga, ani do sił kosmosu.

W ramach etyki pytamy o porządek moralny, czyli o wartości i normy. Etyka stawia także pytanie o grunt moralności. Jaka etyka jest dzisiaj potrzebna? Skąd się wywodzi moralność i do czego można ją sprowadzić? Jaka forma etyki pomaga nam lepiej rozumieć, czym jest dobre życie? Wydaje się, że w tym kontekście wciąż aktualne pozostają uwagi Tischnera nt. inspiracji chrześcijańskich we współczesnej filozofii - w odniesieniu do ludzkiej nadziei, wartości oraz antropologii. Jego zdaniem, chrześcijaństwo w etyce tkwi nie w dogmacie czy określonych tezach, ale w sposobie myślenia, które poszerza krąg aksjologicznego doświadczenia człowieka. 
Ostatnim referatem w tej części obrad było wystąpienie ks. dr. hab. Andrzeja Kobylińskiego z Uniwersytetu Kardynała Stefana Wyszyńskiego w Warszawie nt. Od etyki neotomistycznej do fenomenologii doświadczenia moralnego: Joseph de Finance, Nicolas Sprokel i Paolo Valori. Mówca ukazał trzy dominujące nurty refleksji etycznej, obecne na Wydziale Filozofii Papieskiego Uniwersytetu Gregoriańskiego w Rzymie w drugiej połowie XX wieku. Pierwszy prąd myślowy to tomizm transcendentalny, który był promowany przez francuskiego jezuitę Josepha de Finance'a. Nicią Ariadny w myśleniu filozoficznym tego autora było dążenie do wypracowania etyki metafizycznej. De Finance opowiadał się za koncepcją bytu w ujęciu św. Tomasza z Akwinu jako korzeniem każdego czynu i źródłem każdej formy działania. Jednocześnie podkreślał dynamiczne ujęcie bytu jako aktu. Akcentował znaczenie nieskończonej otwartości ducha ludzkiego i funkcję wolnej woli człowieka. De Finance odrzucał przesadny intelektualizm Arystotelesa, obecny w wielu nurtach tomizmu. Głównym celem jego dociekań była analiza fenomenologiczna doświadczenia moralnego oraz zachowanie fundamentu metafizycznego moralności.

Drugi prąd myślowy był związany z filozofią egzystencji Martina Heideggera. W refleksji etycznej reprezentował go holenderski jezuita Nicolas Sprokel. Heidegger odrzucał etykę jako odrębną dziedzinę wiedzy, natomiast poruszał szeroko rozumianą problematykę etyczną, stawiając fundamentalne pytania o troskę, lęk, śmiertelność, winę, czasowość, samotność czy zew sumienia. Zdaniem Heideggera, nie jest możliwa etyka jako doktryna dotycząca powinności i wartości. W swoich analizach dzieła Heideggera Sprokel podkreślał, że autor Bycia i czasu opowiadał się za ethosem jako sposobem życia człowieka na ziemi, który daje normę do kroczenia, aby być naprawdę sobą.

Trzeci prąd myślowy to etyka fenomenologiczna, której zwolennikiem był włoski jezuita Paolo Valori. Jego zdaniem, fenomenologia wypracowuje sądy wartościujące o charakterze etycznym i odsłania wartości moralne, ale nie tematyzuje ich fundamentu ontologicznego. Analiza fenomenologiczna może doprowadzić do stwierdzenia, że zamordowanie osoby niewinnej i bezbronnej jest złem, ponieważ niszczy mieszkającą w niej godność. Ale fenomenologia nie może powiedzieć, 
dlaczego ostatecznie osoba posiada taką godność i w takiej wyjątkowej mierze. Odkrycie fenomenologiczne wartości moralnej okazuje się w pewnym sensie abstrakcyjne i nieskuteczne, jeśli nie zostaje rozwiązany także problem jej uzasadnienia ontologicznego.

Zwieńczeniem sesji przedpołudniowej była dyskusja panelowa, której przewodniczył dr Sebastian Gałecki z Uniwersytetu Papieskiego Jana Pawła II w Krakowie. W dyskusji został podjęty m.in. problem specyfiki etyki chrześcijańskiej i inspiracji chrześcijańskich w etyce, wyzwań stawianych obecnie refleksji etycznej przez chrześcijaństwo pentekostalne, różnorodności koncepcji filozoficznych obecnych dzisiaj w katolicyzmie i innych odłamach chrześcijaństwa.

Sesji popołudniowej przewodniczył dr Piotr Duchliński, prodziekan Wydziału Filozoficznego Akademii Ignatianum w Krakowie. Pierwszy referat po przerwie obiadowej wygłosił prof. PAN dr hab. Wiesław Wójcik z Polskiej Akademii Nauk nt. Etyka dialogiczna jako odpowiedź na sytuacje graniczne. Myślenie dialogiczne akcentuje zagadnienie mowy jako szczególnego sposobu zwrócenia się naszego ,ja” do innych ludzi. Prelegent z Polskiej Akademii Nauk przywołał w tym kontekście kategorię pracy, która dla Tischnera stanowiła formę myślenia i dialogu par excellence. Warunkiem wszelkiego dialogu jest doświadczenie sytuacji granicznych, na przykład absolutnej samotności czy obcości, które są zaprzeczeniem bliskości. Sytuacją graniczną jest także doświadczenie biedy, która przybiera postać biedy ekonomicznej bądź tzw. biedy fundamentalnej, określającej kondycję człowieka. W sytuacjach granicznych przychodzą nam z pomocą niektóre z cnót: miłosierdzie, wielkoduszność czy wspaniałomyślność.

Drugim referatem w sesji popołudniowej było wystąpienie ks. prof. UP JP II dr hab. Grzegorza Hołuba SDB z Uniwersytetu Papieskiego Jana Pawła II w Krakowie nt. Etyka chrześcijańska a bioetyka chrześcijańska. Mówca przywołał stanowisko Hansa Reichenbacha, dla którego filozofia chrześcijańska istnieje nie na poziomie metod, ale inspiracji. W konsekwencji filozofia chrześcijańska i bioetyka chrześcijańska powinny ukazywać swoją specyfikę nie na poziomie uzasadniania, ale na płaszczyźnie odkrywania. Bioetyka chrześcijańska jest częścią etyki szczegółowej i łączy w sobie trzy gałęzie wiedzy: teorię bytu, antropologię i nauki biomedyczne. 
Na różnice między bioetyką chrześcijańską a bioetyką laicką zwrócił uwagę w swoich pracach m.in. Hugo Tristram Engelhardt. Jego zdaniem, bioetyka chrześcijańska jest skoncentrowana na osobie i czerpie wiele swoich inspiracji z przestrzeni religijnej. $Z$ tego względu zachowuje charakter wyznaniowo-światopoglądowy i broni istnienia uniwersalnych zasad moralnych. Natomiast bioetykę laicką cechuje rys teoriopoznawczy. Zdaniem Engelhardta, tego rodzaju bioetyka kwestionuje istnienie obiektywnych prawd odnoszących się do moralności i oddziela refleksję bioetyczną od fundamentu uniwersalnych zasad moralnych.

Trzeci referat w tej części obrad wygłosił dr hab. Marek Rembierz z Uniwersytetu Śląskiego w Katowicach nt. Między metafizyką moralności a etyka wychowawcza - teoretyczne i praktyczne wymiary refleksji moralnej. Na początku tego wystąpienia został podjęty problem koncepcji etyki niezależnej w wydaniu Tadeusza Kotarbińskiego. Ta twórcza inicjatywa intelektualna wybitnego polskiego filozofa wzbudziła przed laty szerokie zainteresowanie wielu środowisk społecznych.

Kotarbiński postulował etykę niezależną od religii. Twierdził, że „dominuje u nas etyka religijnie ugruntowana. Uzasadnia ona własne hasła naczelne, odwołując się do Boga, do życia przyszłego, do pośmiertnego wymiaru nagród i kar za czyny dobre i złe. Jest jednak spora ilość ludzi nie wierzących ani w istnienie Opatrzności, ani w życie przyszłe. Ci więc potrzebują etyki, która by się obywała bez takich uzasadnień. A przyda się ona także i osobom wierzącym w przypadku zachwiania się lub zgoła utraty wiary religijnej, co zdarza się często. Źle, jeżeli wraz z wiarą załamuje się etyka”.

Zdaniem Marka Rembierza, potrzebujemy dzisiaj adekwatnych modeli etyki niezależnej oraz wychowania i samowychowania jako troski o naszą godność. Dla wychowania moralnego ciągle żywą inspiracją pozostaje starożytna maksyma Owidiusza: „Widzę i pochwalam rzeczy lepsze, lecz wybieram gorsze”. Dobra nie możemy wypowiedzieć do końca i w całości. Dlatego do istotnych elementów każdego modelu etycznego należy jego wymiar apofatyczny.

Czwartym referatem w sesji popołudniowej było wystąpienie dr Magdaleny Kozak z Uniwersytetu Papieskiego Jana Pawła II w Krakowie nt. O tym, co łaczy i dzieli Tischnera i Lévinasa w perspektywie etyki chrześcijańskiej. Nie ulega wątpliwości, że filozofia Lévinasa odcisnęła 
swoje głębokie piętno na twórczości Tischnera. U obydwu autorów mamy do czynienia z paradygmatem „ty” - wszystko rozpoczyna się od spotkania. Lévinas i Tischner widzą też podobnie rolę doświadczenia „Innego”, od którego zależy sens świata. W tym ujęciu w relacji z drugim człowiekiem doświadczamy Transcendencji. Tischner doceniał wysiłki Lévinasa, dotyczące wypracowania nowej metafizyki o charakterze dialogicznym: podzielał jego opinię, że po Auschwitz i niewyobrażalnych zbrodniach XX wieku nie jest już możliwa metafizyczna wizja świata w ujęciu klasycznym. Po Auschwitz i Kołymie źródłem sensu powinno być dobro, które się nigdy nie wyczerpuje.

Obydwaj autorzy poddawali ostrej krytyce systemy totalitarne: Lévinas kierował ostrze swojej krytyki przeciw narodowemu socjalizmowi, natomiast Tischner koncentrował się na krytyce komunizmu. Obydwaj twierdzili, że europejskie myślenie totalizujące przyczyniło się do narodzin trzech systemów totalitarnych: komunizmu, faszyzmu i narodowego socjalizmu. Gdy chodzi natomiast o różnice między Lévinasem a Tischnerem, zdaniem Magdaleny Kozak, warto podkreślić m.in. odmienne rozumienie Transcendencji oraz wprowadzenie przez Tischnera koncepcji człowieka jako istoty dramatycznej oraz podkreślenie znaczenia kategorii łaski - dobro jest łaską, ostatecznie wszystko jest darmo dane.

Kolejny referat w sesji popołudniowej wygłosił dr Andrzej Gielarowski z Akademii Ignatianum w Krakowie nt. Wokół źródłowego doświadczenia etycznego. Prelegent skoncentrował się w swoim wystąpieniu na poglądach francuskiego filozofa Michela Henry’ego, który zajmował się podmiotowością, prawdziwym życiem człowieka. Chciał odrzucić tradycyjny dualizm ciała i duszy. Jego myśl jest zakorzeniona w fenomenologii i rozwija w oryginalny sposób tę tradycję, zwłaszcza jej wersję francuską. Michel Henry może być uznany, obok Emmanuela Lévinasa, Paula Ricoeura czy Jean-Luca Mariona, za jednego z najbardziej twórczych fenomenologów francuskich. Zdaniem Andrzeja Gielarowskiego, człowiek w ujęciu Henry’ego jest monadą aktywną i bierną. Francuskiego filozofa interesowało w sposób szczególny tzw. ukrywanie się Transcendencji i jej dynamiczna relacja z immanencją. Dla Henry'ego nieskończone życie jest jedynym absolutem. Normatywny charakter życia łączy się z jego relacją do dobra, a etyka jest teorią działania moralnego. 
Szósty referat w tej części obrad wygłosił ks. dr Stanisław Łucarz SJ z Akademii Ignatianum w Krakowie nt. Źródła etyki chrześcijańskiej. Jego zdaniem, ciągle zachowuje swoją aktualność antropologia Ojców Kościoła, którzy dokonali syntezy pewnych elementów myśli Greków z filozofią chrześcijańską. Antropologia patrystyczna podkreśla, że Bóg stwarzający człowieka jako Trójca Przenajświętsza jest w swej najgłębszej istocie relacją daru: Bóg jako dar stwarza człowieka, który staje się darem. W ten sposób człowiek zostaje stworzony na obraz i podobieństwo Boże. Człowiek powinien w swym życiu dążyć do tego, aby się upodobnić do Stwórcy według możności.

Ostatnim wystąpieniem w sesji popołudniowej był referat ks. dr. Antoniego Jarnuszkiewicza SJ z Akademii Ignatianum w Krakowie nt. Warunki poznania prawa naturalnego. Prelegent zauważył, że dzisiaj wiele osób nie zgadza się z tym, że istnieje prawo naturalne. Jak zatem docierać do ludzi inaczej myślących? Jak bronić fundamentu metafizycznego etyki? Tego rodzaju pytania rodzą się m.in. w konfrontacji z twórczością Lévinasa, który postulował postrzeganie drugiego jako fenomenu nasyconego Transcendencją. Należy odkryć w sobie nasycenie Transcendencją, bo dusza to „Inny” we mnie.

W podsumowaniu V Ogólnopolskiego Konwersatorium z cyklu Styczeń - Ślipko - Tischner. Inspiracje chrześcijańskie w etyce zwrócono uwagę m.in. na potrzebę bardziej precyzyjnego ukazywania podobieństw i różnic między Lévinasem a Tischnerem. Poważnym błędem jest zbyt powierzchowne utożsamianie ze sobą tych dwóch koncepcji filozoficznych. Lévinas, w odróżnieniu od Tischnera, nie był filozofem dialogu. W tym kontekście ks. prof. Ryszard Moń przywołał swoją rozmowę z ks. Tischnerem, która miała miejsce w Krakowie w połowie lat 90. ubiegłego wieku. W trakcie tego spotkania Tischner powiedział, że przyjęcie wszystkich - czasami zbyt kategorycznych - propozycji Lévinasa sprawia, iż jego etyka staje się wręcz nieludzka. Zdaniem Monia, na gruncie filozofii Lévinasa tego rodzaju obawy są nieuzasadnione. Tischner dokonał korekty koncepcji Lévinasa, tworząc własną filozofię dialogu i dramatu, która jest bliższa człowiekowi i uwzględnia podstawowe zasady antropologii chrześcijańskiej.

Na zakończenie obrad została podjęta wspólna decyzja, że kolejne konwersatorium będzie poświęcone myśleniu postmetafizycznemu 
i różnym modelom etyki, tworzonym w sporze z nihilizmem. Zamknięcia konferencji dokonał ks. dr Stanisław Łucarz SJ, dyrektor Instytutu Filozofii Akademii Ignatianum w Krakowie.

ANDRZEJ KOBYLIŃSKI

Instytut Filozofii UKSW, Warszawa

\section{SPRAWOZDANIE Z MIĘDZYNARODOWEJ KONFERENCJI NAUKOWEJ SOCIO-ETHICAL IDEAS OF CONTEMPORARY RUSSIAN PHILOSOPHY IN THE CONTEXT OF SLAVIC WORLD, TRNAVSKA UNIVERZITA, TRNAWA, 5 MAJA 2015}

5 maja 2015 roku na Uniwersytecie Trnawskim na Słowacji odbyła się międzynarodowa konferencja naukowa nt. Idee spoteczno-etyczne wspótczesnej filozofii rosyjskiej w kontekście świata stowiańskiego. Sympozjum zostało zorganizowane przez Sekcję Etyki i Filozofii Moralnej Wydziału Filozoficznego Uniwersytetu Trnawskiego. Spotkanie zgromadziło przedstawicieli kilkunastu środowisk uniwersyteckich z Czech, Polski, Rosji i Słowacji. Tegoroczna konferencja stanowiła kolejny etap realizacji trzyletniego grantu VEGA nr 1/0061/14 nt. Socio-ethical themes in contemporary Russian philosophy, realizowanego w latach 2014-2017 przez pracowników naukowych Uniwersytetu Tarnawskiego, przy współpracy m.in. Sekcji Etyki Wydziału Filozofii Chrześcijańskiej Uniwersytetu Kardynała Stefana Wyszyńskiego w Warszawie.

Pierwszym etapem realizacji tego projektu badawczego była międzynarodowa konferencja naukowa nt. Współczesne trendy ,, spoteczno-etyczne" i problem sprawiedliwości w kontekście Europy Środkowej oraz we współczesnej myśli rosyjskiej, która miała miejsce 4 listopada 2014 roku na Uniwersytecie Trnawskim. Sympozjum zostało zorganizowane przez Sekcję Etyki i Filozofii Moralnej Wydziału Filozoficznego Uniwersytetu Trnawskiego oraz Sekcję Etyki Wydziału 